\title{
Universiteit
}

Leiden

The Netherlands

\section{The Netherlands: Political development and data for 2018.}

Otjes, S.; Voerman, G.

\section{Citation}

Otjes, S., \& Voerman, G. (2019). The Netherlands: Political development and data for 2018. European Journal Of Political Research Political Data Yearbook, 58(1), 198-204. doi:10.1111/2047-8852.12261

Version: Publisher's Version

License: $\quad$ Creative Commons CC BY-NC-ND 4.0 license

Downloaded from: $\quad$ https://hdl.handle.net/1887/3200493

Note: To cite this publication please use the final published version (if applicable). 


\title{
The Netherlands: Political Developments and Data in 2020
}

\author{
SIMON OTJES ${ }^{1,2}$ \& LAURIEN HANSMA ${ }^{2}$ \\ ${ }^{1}$ Institute of Political Science, Leiden University, the Netherlands; ${ }^{2}$ Documentatiecentrum Nederlandse \\ Politieke Partijen, University of Groningen, the Netherlands
}

\section{Introduction}

Much like the rest of the world, the Covid-19 pandemic held Dutch society, the economy and the political system in its grip in 2020. In the meantime, the Rutte III Cabinet, which had become a minority Cabinet in the last year, continued to govern by striking deals with opposition parties.

\section{Cabinet report}

The year 2019 saw several Cabinet members leaving and new members arriving. On 29 January, two successors were appointed to fill the vacancy left by Menno Snel in 2019, who had to resign over an issue involving childcare allowances (Otjes \& Voerman 2020): Alexandra van Huffelen Democrats 66/Democraten 66 (D66) became state secretary responsible only for this allowance issue and the customs agency. Hans Vijlbrief (D66) became state secretary responsible for tax policy.

On 19 March, Bruno Bruins, the Liberal Party/Volkspartij voor Vrijheid en Democratie (VVD) Minister for Medical Care and Sport, stepped down because he was fatigued due to the weight of the Covid-19 crisis. Christian-Democratic Appeal/Christen-Democratisch Appèl (CDA) minister Hugo de Jonge took over his Corona portfolio. Four days later, Bruins was succeeded as minister by Martin van Rijn, who had been state secretary at the Ministry of Health, Welfare and Sport in the Rutte II Cabinet (2012-17). Van Rijn was a member of the Labour Party/Partij van de Arbeid (PvdA), an opposition party, but was appointed as minister on personal title and served in a non-partisan capacity. On 9 July 2020, Van Rijn was replaced by Tamara van Ark (VVD), who was State Secretary of Social Affairs and Employment in the current Cabinet. As State Secretary of Social Affairs and Employment, she was succeeded by Liberal MP Bas van 't Wout.

In the fall of 2019, Kajsa Ollongren (D66) had stepped down due to health reasons (Otjes \& Voerman 2020). Her portfolios had been redistributed between several ministers and state secretaries. On 14 April, Ollongren was reinstated as Minister for Home Affairs and Kingdom Relations and the other officials returned to their positions (in particular, Raymond Knops (CDA), who had been Minister of Home Affairs and Kingdom Relations, and Stientje van Veldhoven (D66), who had been Minister for the Environment and Housing). On 14 May, Ollongren also was reinstated as Vice-Prime Minister taking over from Wouter Koolmees. 


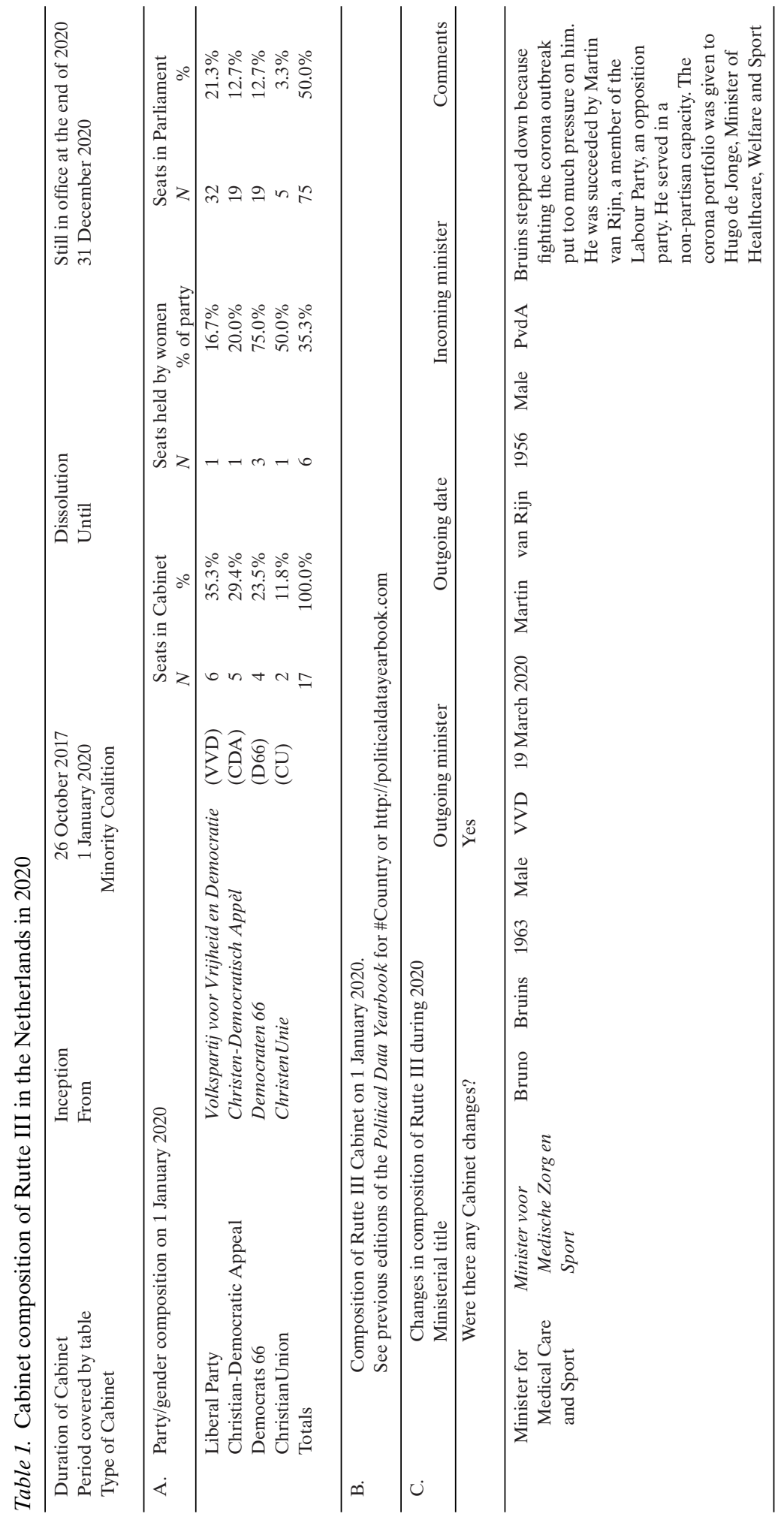




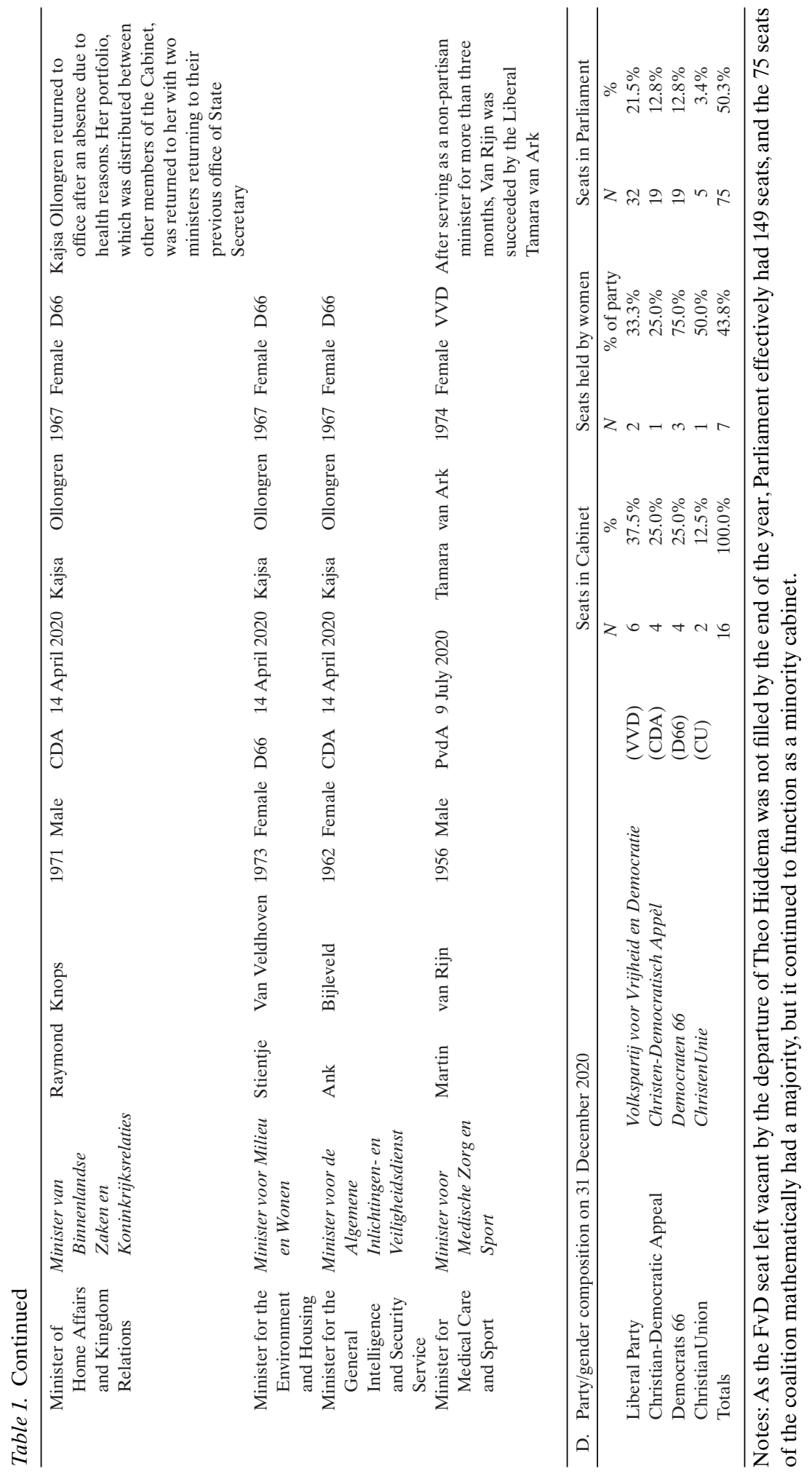




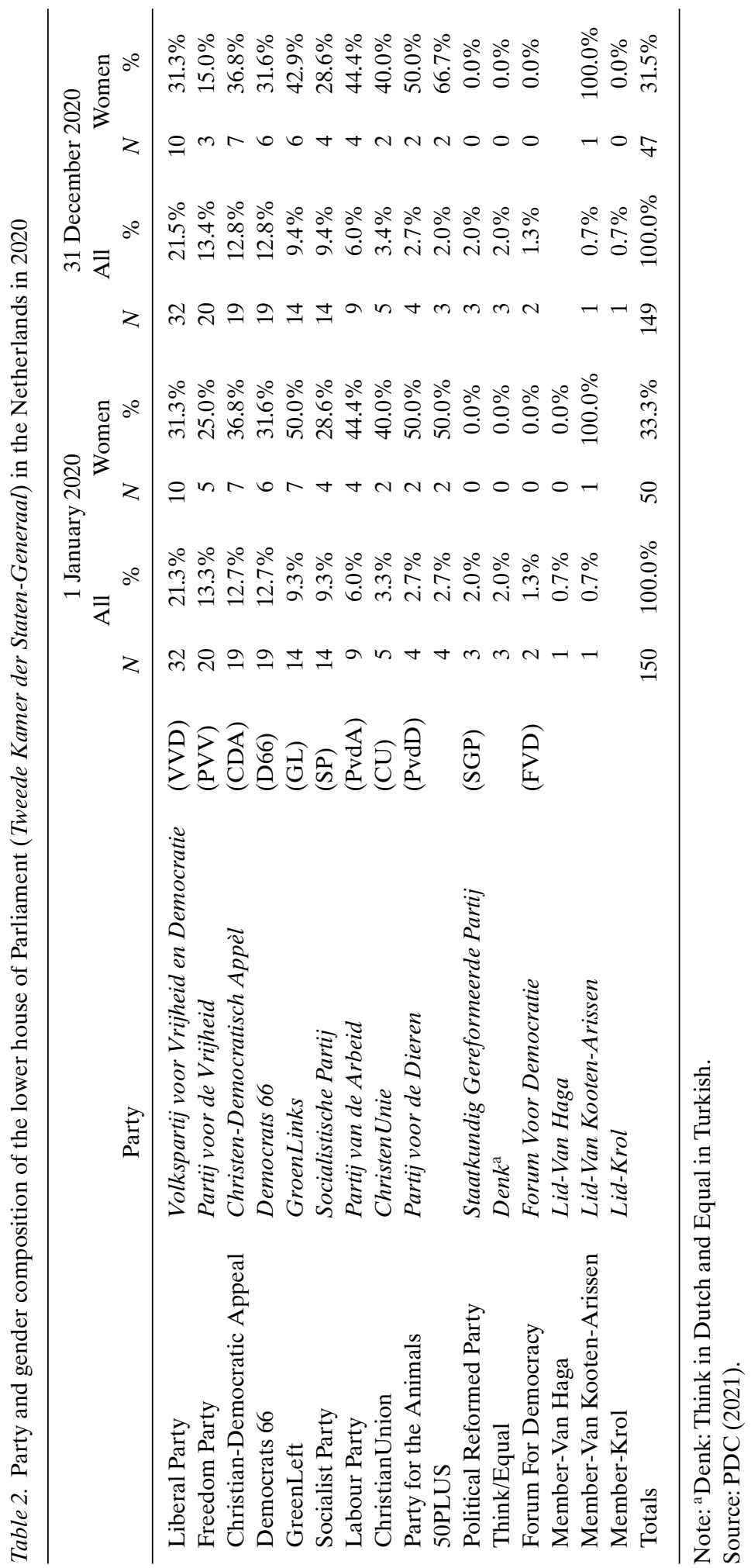




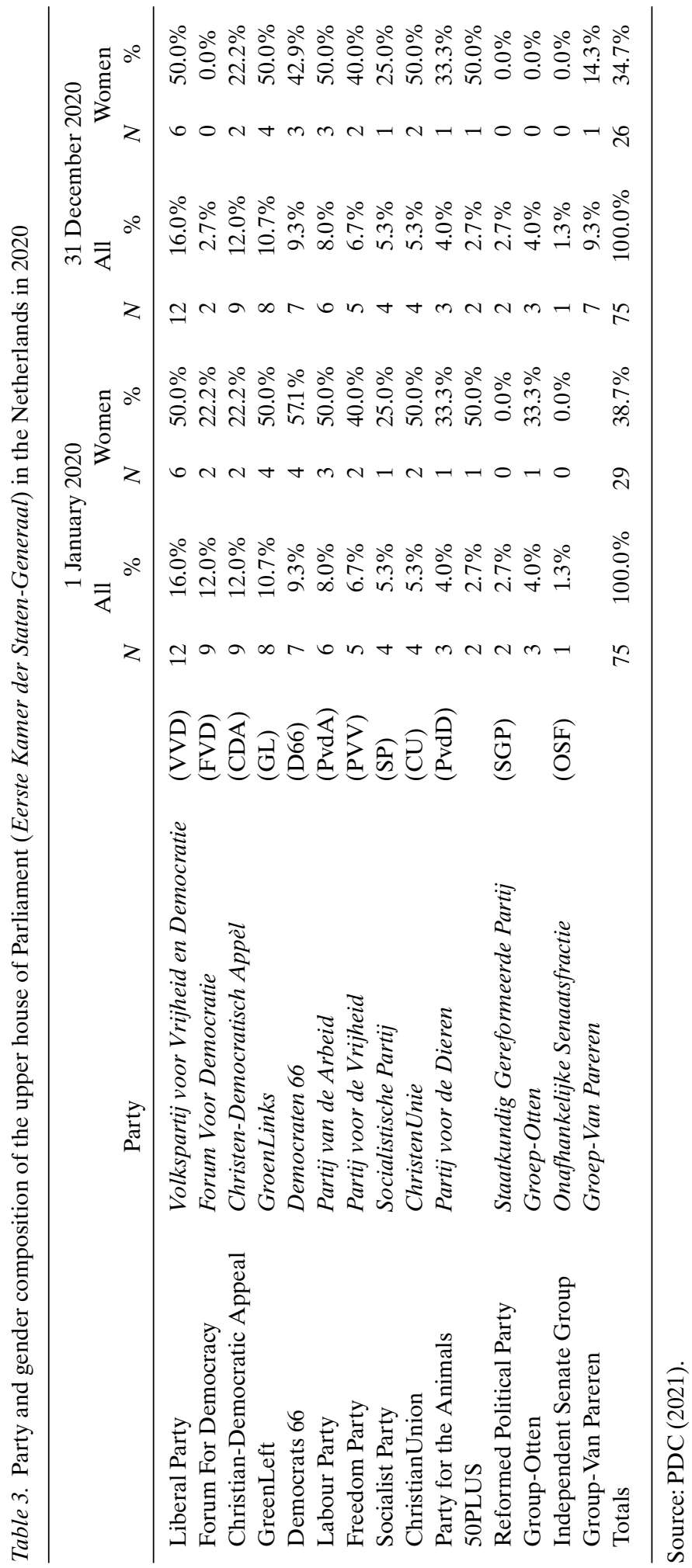




\section{Parliament report}

The activities of Parliament were strongly impacted by Covid-19. Between 15 March and 15 April, Parliament only organized debates related to the Covid-19 crisis. After that parliamentary activity geared up. Only a limited number of MPs were allowed to be present in plenary meetings, leading to a formalization of the principle that MPs are expected to vote as their party group, except for roll call votes.

On 3 May, Henk Krol left the 50PLUS group that he had chaired after ongoing internal conflicts in the 50PLUS party. He then joined several party groups (detailed below in the political party report), ending up an independent MP.

On 21 May, Wybren van Haga, an independent MP, who had been removed from the VVD parliamentary party group in 2019, announced that he had joined Forum voor Democratie and that he would run in the 2021 elections for that party. On 1 December, he officially joined the Forum For Democracy/Forum Voor Democratie (FVD) parliamentary party group. As part of a larger conflict in the FVD (see below in political party report), FVD MP Theo Hiddema left Parliament on 25 November. His seat was still vacant by the end of the year. This conflict also led to a split in the FVD group with only two senators remaining loyal to the party.

\section{Political party report}

Parties in Parliament began preparing for elections to be held in 2021: compiling candidate lists, composing election manifestos and selecting leaders. This led to several leadership changes. On 21 March, Farid Azarkan became leader of Think/Equal/Denk's parliamentary party group and headed the party's 2021 list. He succeeded Tunahan Kuzu, who stepped down as leader due to an extramarital affair with an employee of Denk.

On 3 May, Henk Krol, leader of the pensioners' party 50PLUS, and MP Merel van Kooten-Arissen, who had left another political party (specifically the Party for the Animals/Partij voor de Dieren - PvdD) in 2019, formed a new group in Parliament and registered a new party, the Party for the Future/Partij voor de Toekomst (PvdT). On 29 June, Krol announced a merger of his PvdT with GO, the party of Henk Otten, that had split from the Forum for Democracy in the Senate, provincial councils and the European Parliament. On 8 August, Van Kooten-Arissen subsequently left the PvdT to continue as an independent MP because she was unhappy with the dominance of Henk Otten in the new party. On 18 October, Krol left the PvdT for similar reasons. A month later, Krol announced that he would run with his own party (List Henk Krol/Lijst Henk Krol-LHK) and, on 21 December, Van Kooten-Arissen announced that she would run with her own party (Splinter/Splinter).

Krol leaving 50PLUS left the party leaderless. He was succeeded by Corrie van Brenk as chair of the 50PLUS group. On 3 October, the party's general assembly elected Liane den Haan, chair of the pensioners' organization General Dutch League for the Elderly, as the new top candidate, beating Van Brenk.

In November, FVD became embroiled in a conflict. It started with a conflict about its youth wing Young FVD/Jong FVD where members shared racist, antisemitic, homophobic and pro-Nazi memes via WhatsApp. This led to a schism in the party between the leader 


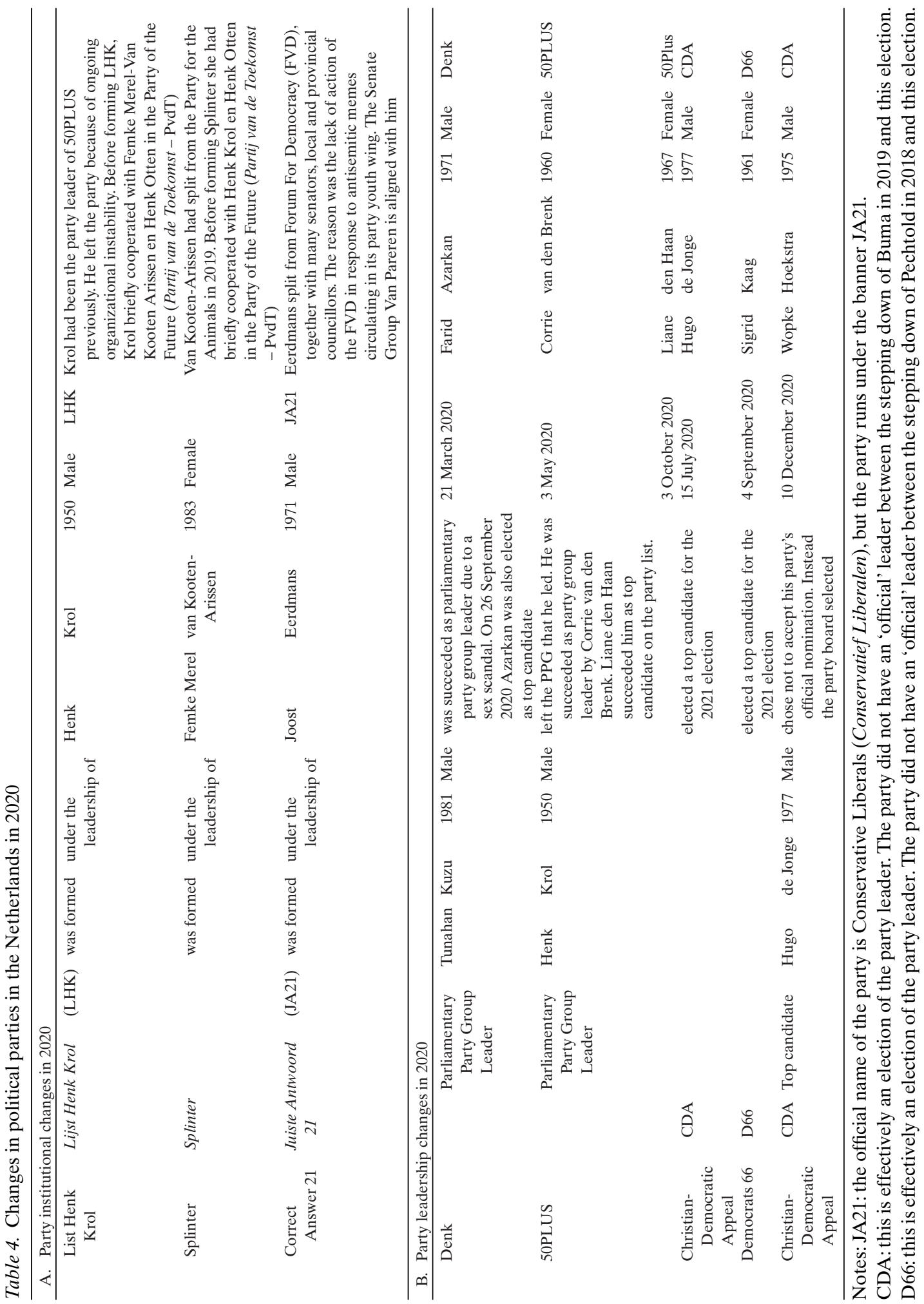


of the party Thierry Baudet and his followers, on the one side, who felt that the youth wing had dealt well with this conflict, and many other FVD politicians, on the other side, who felt that party should distance itself more strongly from antisemitism. This latter group was led by Senator Annabel Nanninga and number four on the proposed FVD list for the 2021 elections Joost Eerdmans. In response to the conflict, Baudet stepped down as party leader on 23 November. Two days later, he announced his return. In response, the group led by Nanninga and Eerdmans left as did the majority of the Senate parliamentary party, half of the party board, the entire European Parliament group and many provincial councillors. By the end of the year, more than half the FVD provincial councillors had left the party. Many of these politicians joined a new party set up by Nanninga and Eerdmans, Correct Answer 21/Juiste Antwoord 21 (JA21). On 4 December, the FVD organized a referendum about who should be its leader, which was won by Baudet.

Two national parties, D66 and CDA, also organized internal referenda. On 15 July, the Minister of Healthcare, Welfare and Sport Hugo de Jonge won the elections for the top spot, beating Mona Keijzer, State Secretary for Economic Affairs and Climate and MP Pieter Omtzigt. On 10 December, he stepped down as leader. De Jonge found it impossible to combine the party leadership with his position as minister responsible for Corona policy. CDA members had feared that growing dissatisfaction with the Corona policy could undermine their party's chances. The party board then selected Wopke Hoekstra, Minister of Finance, who had backed out of the leadership race in the summer, as his successor. The CDA congress in 2021 would formally appoint him. On 4 September, Sigrid Kaag, Minister of Foreign Trade and Development Cooperation, was elected to the top position on D66's list without serious competition.

Other parties did not hold elections but selected the current party leader as top candidate: Geert Wilders would run for the Freedom Party/Partij voor de Vrijheid (PVV), the Socialist Party/Socialistische Partij (SP) selected Lilian Marijnissen, GreenLeft/GroenLinks (GL) selected Jesse Klaver, the ChristianUnion/ChristenUnie (CU) selected Gert-Jan Segers, the PvdD selected Esther Ouwehand and the Political Reformed Party/Staatkundig Gereformeerde Partij (SGP) selected Kees van der Staaij. Lodewijk Asscher was the only candidate for the top spot for the Labour Party, and Mark Rutte was the only candidate for the Liberal Party's top spot, but the party congresses in 2021 still had to formally appoint them.

\section{Institutional change report}

Some constitutional changes were considered by Parliament related to the electoral system, the referendum and the Senate.

On 1 July, Minister of Home Affairs and Kingdom Relations Kajsa Ollongren proposed a change in the electoral law that would increase the impact of preference votes. This proposal had been made in 2018 earlier by the State Committee-Remkes. The proposal was not voted on and would not affect the 2021 elections.

On 22 September, the lower house of Parliament accepted a first reading of the Referendum Bill, which was a private member of bill of SP MP Ronald van Raak. The 
goal would be to introduce a binding corrective referendum. The introduction of such a referendum was proposed by the State Committee.

On 8 December, the lower house of Parliament accepted a first reading of a bill aimed at reforming the election method of the Senate: it would not be elected for one four-year term, but instead half the Senators would be elected every six years.

\section{Issues in national politics}

Like other countries the healthcare, economic and societal fallout of the Covid-19 outbreak dominated the political events in this year. The Netherlands imposed quarantine measures on 11 March, which were labelled the 'intelligent lock-down'. On 16 March, the Prime Minister held a televised address about the Corona crisis; the first such address in almost 50 years. Lockdown measures were gradually lifted in the summer. In December, lockdown measures were reimposed. On 14 December, the Prime Minister held another televised address to announce a new lockdown.

Crisis measures were coordinated by the Ministerial Crisis Management Committee, which was advised by the Outbreak Management Team of medical specialists. A legal basis for the crisis measures came in the form of the temporary law Covid-19, which was accepted in Parliament with the support of the coalition, the PvdA, GL, 50PLUS and SGP.

To counteract the economic effect of the crisis, the Dutch government initiated several relief measures. On 31 March, Minister for Social Affairs and Employment Koolmees introduced the Temporary Emergency Bridging Measure for the Preservation of Employment, which would take over 90 per cent of the labour costs of companies under stress, which was renewed in May and September. Specific measures were also taken to support independent contractors, the Dutch airline KLM, the cultural sector and other affected sectors.

In the fall, the Cabinet bargained with the left-wing GreenLeft and the Labour Party for support for the budget. The most contentious issues were the tax plan and the housing budget. On 6 November, a deal was struck between the coalition, GL and the Labour Party. The opposition parties supported the housing budget after getting measures to limit rent increases, but they did not support the tax plan, which included a tax break for companies. For the tax plan the government relied on support of FVD and Group-Otten/Groep-Otten.

Another key issue in the previous year had been the nitrogen crisis. The highest administrative court had decided in 2019 that the regulations aimed to stop nitrogen emissions were insufficient. On 9 December 2020, the coalition struck a deal with the SP, 50PLUS and SGP about a new bill aimed to stop nitrogen emissions. This was the first time that the left-wing populist SP had backed a bill after specifically bargaining with the government about its contents.

Migration continued to divide the government. Decision-making on this issue gained momentum after several fires broke out in an overcrowded refugee camp in Moria on the Greek island of Lesbos on 9 September. Coalition parties ChristianUnion and D66 demanded quick action from the Cabinet. The final decision to take in 100 young refugees from Moria was considered a breakthrough for the ChristianUnion and D66. As a compromise, however, the Liberal Party demanded that this number of refugees would 
be deducted from the 2000 that the Netherlands had promised the United Nations High Commissioner for Refugees to take in.

On 17 December, a parliamentary research committee into the allowance issue (which led to Snel stepping down in 2019) presented its report Ongekend Onrecht (Unprecedented Injustice). It concerned the persecution of suspected fraud with allowances for childcare costs by the tax authorities. More than 9000 families were punished disproportionally for small errors, which were classified as fraud by the tax services. The efforts of the tax services were specifically targeted at ethnic minorities. The committee concluded that in the persecution of allowance fraud the government had violated basic principles of the rule of law and that government ministers had not informed Parliament correctly and completely.

\section{Sources}

PDC. (2021) Bibliographic Archive. www.parlement.com.

Otjes, S., \& Voerman, G. (2020). The Netherlands: Political developments and data in 2019. European Journal of Political Research Political Data Yearbook, 261-271, 59(1). 